\title{
Analyzing Chat Conversations of Pedophiles with Temporal Relational Semantic Systems
}

\author{
Paul Elzinga ${ }^{1}$, Karl Erich Wolff ${ }^{2}$, Jonas Poelmans ${ }^{3,4}$, Guido Dedene ${ }^{3,5}$, and \\ Stijn Viaene ${ }^{3,6}$ \\ 1 Amsterdam-Amstelland Police \\ James Wattstraat 84, 1097DM Amsterdam, The Netherlands \\ paul.elzinga@amsterdam.politie.nl \\ 2 Ernst-Schröder-Center, Darmstadt University of Technology \\ Schloßgartenstr. 7, D-64289 Darmstadt, Germany \\ karl.erich.wolff@t-online.de \\ 3 K.U.Leuven, Faculty of Business and Economics, Naamsestraat 69, 3000 Leuven, \\ Belgium \\ 4 National Research University Higher School of Economics (HSE) \\ Pokrovskiy boulvard 11, 101000 Moscow, Russia \\ jonas. poelmans@econ. kuleuven. be \\ 5 Universiteit van Amsterdam Business School \\ Roetersstraat 11, 1018 WB Amsterdam, The Netherlands \\ Guido.Dedene@econ.kuleuven.be \\ ${ }^{6}$ Vlerick Leuven Gent Management School, Vlamingenstraat 83, 3000 Leuven, \\ Belgium \\ Stijn.Viaene@econ.kuleuven.be
}

\begin{abstract}
Grooming is the process by which pedophiles try to find children on the internet for sex-related purposes. In chat conversations they may try to establish a connection and escalate the conversation towards a physical meeting. Till date no good methods exist for quickly analyzing the contents, evolution over time, the present state and threat level of these chat conversations. In this paper we propose a novel method based on Temporal Relational Semantic Systems, the main structure in the temporal and relational version of Formal Concept Analysis. For rapidly gaining insight into the topics of chat conversations we combine a linguistic ontology for chat terms with conceptual scaling and represent the dynamics of chats by life tracks in nested line diagrams. To showcase the possibilities of our approach we used chat conversations of a private American organization which actively searches for pedophiles on the internet.
\end{abstract}

Keywords: Formal Concept Analysis, Temporal Concept Analysis, Conceptual Scaling, Relational Systems, Nested Line Diagrams, Transition Diagrams

Acknowledgment Jonas Poelmans is Aspirant of the "Fonds voor Wetenschappelijk Onderzoek - Vlaanderen" (FWO) or Research Foundation - Flanders. 


\section{References}

[1] Chein, M., Mugnier, M.-L.: Graph-based Knowledge Representation. Computational Foundations of Conceptual Graphs. Springer-Verlag London Limited (2009)

[2] Chen, H., Chung, W., Xu, J.J., Wang, G., Qin, Y., Chau, M.: (2004) Crime data mining: a general framework and some examples. IEEE Computer, April (2004)

[3] Dau, F.: The Logic System of Concept Graphs with Negation And Its Relationship to Predicate Logic. LNAI 2892, Springer, Heidelberg (2003).

[4] Dombrowski, S.C., Gischlar, K.L., Durst, T.: Safeguarding young people from cyber pornography and cyber sexual predation: a major dilemma of the internet. Child abuse review, Vol. 16, pp. 153-170 (2007).

[5] Elzinga, P., Poelmans, J., Viaene, S., Dedene, G., Morsing, S. : Terrorist threat assessment with Formal Concept Analysis. Proc. IEEE International Conference on Intelligence and Security Informatics. May 23-26, 2010 Vancouver, Canada. ISBN 978-1-42446460-9/10, pp.77-82. (2010)

[6] Ganter, B., Wille, R.: Formal Concept Analysis: Mathematical Foundations. Springer, Heidelberg (1999); German version: Springer, Heidelberg (1996)

[7] Gottschalk, P.: A dark side of computing and information sciences: characteristics of online groomers. The Journal of Emerging Trends in Computing and Information Sciences, Vol. 2, No. 9, pp. 447-455, September (2011).

[8] Huchard, M., Rouane-Hacene, M., Cyril Roume, Valtchev, P.: Relational concept discovery in structured datasets. Ann. Math. Artif. Intell. 49(1-4), pp. 39 76.(2007)

[9] IALEIA: Law Enforcement Analytic Standards. Richmond, VA: Global Justice Information Sharing Initiative.(2004)

[10] Krippendorf, K.: The Content analysis Reader. With M. A. Bock (Eds.). Thousand Oaks, CA: Sage, 481 pp.(2008)

[11] Poelmans, J., Elzinga, P., Viaene, S., Dedene, G. . A case of using formal concept analysis in combination with emergent self organizing maps for detecting domestic violence, Lecture Notes in Computer Science, 5633, pp. 247 - 260, Advances in Data Mining. Applications and Theoretical Aspects, 9th Industrial Conference (ICDM), Leipzig, Germany, July 20-22, 2009, Springer (2009)

[12] Poelmans, J., Elzinga, P., Viaene, S., Dedene, G. : Curbing domestic violence: Instantiating C-K theory with Formal Concept Analysis and Emergent Self Organizing Maps. Intelligent Systems in Accounting, Finance and Management 17, (3-4), pp. 167-191. Wiley and Sons, Ltd. doi 10.1002/isaf.319 (2010)

[13] Poelmans, J., Elzinga, P., Viaene, S., Dedene, G., Kuznetsov, S. : A concept discovery approach for fighting human trafficking and forced prostitution. Lecture Notes in Computer Science 6828, pp. 201-214, 19th International conference on conceptual structures, July 25-29, Derby, England. Springer (2011)

[14] Poelmans, J., Elzinga, P., Neznanov, A., Kuznetsov, S., Dedene, G., Ignatov, D., Viaene, S. : Concept relation discovery and innovation enabling technology (CORDIET). D. Ignatov et al. (Eds.): Proceedings of the International Workshop on Concept Discovery in Unstructured Data, 25 June, Moscow, Russia, pp. 53 62. ISSN 1613-0073.(2011)

[15] Prediger, S.: Kontextuelle Urteilslogik mit Begriffsgraphen. Ein Beitrag zur Restrukturierung der mathematischen Logik. Dissertation, TU Darmstadt 1998. Shaker, Aachen (1998)

[16] Ratcliffe, J.: Intelligence-Led Policing. Collumpton, UK Willan Publishing (2008) 
[17] Sowa, J.F.: Conceptual structures: information processing in mind and machine. Adison-Wesley, Reading (1984)

[18] Sowa, J.F.: Knowledge representation: logical, philosophical, and computational foundations. Brooks Cole Publ. Comp., Pacific Grove, CA (2000)

[19] Wille, R.: Restructuring Lattice Theory: an Approach based on Hierarchies of Concepts. In: Rival, I. (ed.): Ordered Sets. pp. 445-470, Reidel, Dordrecht-Boston (1982). Reprinted in: Ferr'e, S., Rudolph, S. (eds.): Formal Concept Analysis. ICFCA 2009. LNAI 5548, pp. 314-339. Springer, Heidelberg (2009)

[20] Wille, R.: Conceptual Graphs and Formal Concept Analysis. In: D. Lukose, H. Delugach, M. Keeler, L. Searle, J.F. Sowa (eds.): Conceptual Structures: Fulfilling Peirce's Dream. LNAI 1257, pp. 290-303. Springer, Heidelberg (1997)

[21] Wolak, J., Finkelhor, D., Mitchell, K.J., Ybarra, M.L.: Online predators and their victims - myths, realities and implications for prevention and treatment. American Psychologist Vol. 63, No. 2, pp. 111-128 (2008)

[22] Wolff, K.E.: Temporal Concept Analysis. In: E. Mephu Nguifo et al. (eds.): ICCS2001 International Workshop on Concept Lattices-Based Theory, Methods and Tools for Knowledge Discovery in Databases, Stanford University, Palo Alto, CA, 91-107 (2001)

[23] Wolff, K.E.: 'Particles' and 'Waves' as Understood by Temporal Concept Analysis. In: K.E. Wolff, H.D. Pfeiffer, H.S. Delugach (eds.): Conceptual Structures at Work. LNAI 3127, pp. 126-141. Springer, Heidelberg (2004)

[24] Wolff, K.E.: States of Distributed Objects in Conceptual Semantic Systems. In: F. Dau, M.L.Mugnier, G.Stumme (eds.): Common Semantics for Sharing Knowledge. LNAI 3596, pp. 250-266. Springer, Heidelberg (2005)

[25] Wolff, K.E.: States, Transitions, and Life Tracks in Temporal Concept Analysis. In: B. Ganter, G. Stumme, R. Wille (eds.): Formal Concept Analysis State of the Art. LNAI 3626, pp. 127-148. Springer, Heidelberg (2005)

[26] Wolff, K.E.: Relational Semantic Systems, Power Context Families, and Concept Graphs. In: Wolff, K.E. et al (eds.): Contributions to ICFCA 2009, pp. 63-78. Verlag Allgemeine Wissenschaft, Darmstadt (2009)

[27] Wolff, K.E.: Relational Scaling in Relational Semantic Systems. In: Rudolph, S. et al (eds.): Conceptual Structures: Leveraging Semantic Technologies. LNAI 5662, pp. 307-320. Springer-Verlag, Heidelberg (2009)

[28] Wolff, K.E.: Temporal Relational Semantic Systems. In: Croitoru et al (eds.): Conceptual Structures: From Information to Intelligence. LNAI 6208, pp. 165180. Springer-Verlag, Heidelberg (2010)

[29] Wolff, K.E.: Applications of Temporal Conceptual Semantic Systems. In: Wolff, K.E. et al (eds.): Knowledge Processing and Data Analysis. LNAI 6581, pp. 59-78. Springer-Verlag, Heidelberg (2011)

[30] Wollbold, J., Wolff, K.E., Huber, R., Kinne, R.: Conceptual Representation of Gene Expression Processes. In: Wolff et al (eds.): Knowledge Processing and Data Analysis. LNAI 6581, pp. 79-100. Springer, Heidelberg (2011) 